\title{
Longitudinal study of mandibular behavior in Class I subjects with vertical and horizontal growth
}

\author{
Dirceu Barnabé Raveli', Savana Maia², Luana Paz Sampaio³, Denise Rocha Goes Landázuri', Taísa Boamorte Raveli
}

Objective: To evaluate possible differences in mandibular behavior in Class I individuals with vertical and horizontal growth patterns. Methods: The sample consisted of 20 untreated Class I individuals divided into: Group 1 comprising 10 individuals with vertical growth pattern and Group 2 comprising 10 individuals with horizontal growth pattern, all of them belonging to the Burlington Growth Center files, University of Toronto-Canada, radiographically followed-up at ages 9, 12 and 21. Cephalometric radiographs, determined mean values for a long-term evaluation of mandibular behavior using the following measurements: SNB, Co-GN, SN.GoMe, anterior facial height and posterior facial height. Results: SNB and CoGn values were higher in horizontal growth group at all of the ages studied; SN.GoMe measure was significantly lower in horizontal growth group; anterior facial height (AFH) showed lower values in individuals with horizontal growth pattern; and posterior facial height (PFH) showed lower values in individuals with vertical growth pattern. Conclusion: Long-term comparisons of Class I individuals' growth tendencies indicate that there are significant differences between both groups. Mandible showed a trend to clockwise rotation in Group 1. Group 2 showed a trend to brachycephalic facial form, due to the deficit in vertical development with regard to anterior facial height.

Keywords: Growth and development. Angle Class I malocclusion. Mandible.

Objetivo: avaliar as possíveis diferenças no comportamento mandibular em indivíduos Classe I com crescimento vertical e horizontal. Métodos: a amostra desse estudo consistiu de 20 indivíduos Classe I não tratados, sendo o grupo 1 composto por 10 indivíduos com padrão de crescimento vertical e o grupo 2 por 10 indivíduos com padrão de crescimento horizontal, pertencentes aos arquivos do Burlington Growth Center, University of Toronto, no Canadá, acompanhados radiograficamente nas idade de 9,12 e 21 anos. Determinou-se, por meio de telerradiografias cefalométricas, em norma lateral, os valores médios para a avaliação longitudinal do comportamento da mandíbula utilizando as medidas SNB, Co-Gn, SN.GoMe, altura facial anterior e altura facial posterior. Resultados: o valor de $\mathrm{SNBe} \mathrm{Co}-\mathrm{Gn}$ foram maiores no grupo com crescimento horizontal em todas as idades. A medida Sn.GoMe foi significativamente menor no grupo com crescimento horizontal, a altura facial anterior (AFH) apresentou valores menores nos indivíduos com padrão de crescimento horizontal, e a altura facial posterior (PFH) apresentou valores menores nos indivíduos com crescimento vertical. Conclusão: as comparações longitudinais das tendências de crescimento de indivíduos Classe I indicam que existe diferenças significativas entre os dois grupos. A mandíbula apresentou tendência à rotação horária no grupo 1 . O grupo 2 exibiu tendência à característica de indivíduos braquicefálicos, na forma facial, devido ao déficit no desenvolvimento vertical na altura facial anterior.

Palavras-chave: Crescimento e desenvolvimento. Má oclusão de Angle Classe I. Mandíbula.

\footnotetext{
${ }^{1}$ Associate Professor of Orthodontics, FOAr/UNESP.

${ }^{2}$ Professor, Amazonas State University.

${ }^{3} \mathrm{PhD}$ in Orthodontics, UNESP/Araraquara. Professor, Specialization Course in Orthodontics, FAMOSP/GESTOS - Araraquara.

${ }^{4} \mathrm{PhD}$ Student, FOAr/UNESP.

${ }^{5} \mathrm{MSc}$ in Orthodontics, UNESP/Araraquara. Professor, Specialization Course in Orthodontics, FAMOSP/GESTOS - Araraquara.

» The author reports no commercial, proprietary or financial interest in the products or companies described in this article.
}

\author{
How to cite this article: Raveli DB, Maia S, Sampaio LP, Landázuri DRG, Raveli TB. \\ A longitudinal study of mandible behavior in Class I individual with vertical and hori- \\ zontal growth. Dental Press J Orthod. 2012 Nov-Dec;17(6):25.el-7. \\ Submitted: October 15, 2008 - Revised and accepted: August 30, 2012 \\ Contact address: Dirceu Barnabé Raveli \\ Rua: Humaitá, 1680 - Centro - Cep: 14801-903 - Araraquara/SP - Brazil \\ E-mail: draveli@foar.unesp.br
}




\section{INTRODUCTION AND LITERATURE REVIEW}

Aiming a safe and correct orientation of the treatment plan for correction of malocclusions, it is necessary to know the pathological and physiological development pattern, on other words, to know the morphological characteristics of Angle's Class I, II and III malocclusions. Sagittal and vertical development of the mandible can be analyzed in longitudinal growth study in samples of untreated Class I individuals.

The craniofacial growth studies of subjects with malocclusion, orthodonticatlly untreated, are important for the assessment of the effects induced by mechanotherapy, since the growth of these individuals is extremely variable, difficult to predict and different when compared to the growth of individuals with normal occlusion, thus complicating the interpretation of the effects of mechanotherapy during growth. ${ }^{28}$

Ngan et $\mathrm{al}^{21}$ conducted a comparative longitudinal study of skeletal changes of subjects with Class I and Class II malocclusion Division 1. It was used a sample of 40 individuals (20 Class I and 20 Class II) ranging from 7 to 14 years. The changes observed in Class II individuals, compared to Class I, are described as follows: The mandible (SNB and SNPog) was significantly more retruded, measures such as (Ar-NG) and (Go-Gn) were found reduced, the Y axis and mandibular plane angle increased, in order to contribute to the retruded position of the mandible in these individuals.

Buschang and Martins ${ }^{7}$ observed the anteriorposterior and vertical skeletal development relationship of mandible of Class I and II individuals from 6 to 15 years. The results showed that the vertical and anterior-posterior relationship are not stable during growth and vary according to age, gender and type of malocclusion.

Chung et $\mathrm{al}^{9}$ analyzed the skeletal and dental morphology of 85 Class II untreated patients, from 9 to 18 years, from the records of Bolton-Brush and Burlington Growth Center. It was investigated the craniofacial growth of those individuals. It was observed a decrease in the mandibular plane angle in all groups and counterclockwise rotation of the mandible, however individuals who had decreased mandibular angle had a greater rotation.
Thilander et $\mathrm{al}^{27}$ conducted a longitudinal study with subjects from 5 to 31 year-old in Swedish population. The sample was composed of cephalometric radiographs of 469 subjects with normal occlusion orthodontically treated. The results showed that the mandibular length increased in male subjects ; mandibular growth spurt occurred between 13 and 16 years of age. They observed continuous decrease of goniac angle and, consequently, mandibular counterclockwise rotation and the SNB angle increased continuously during the observation period (77 to 81 degrees) in these individuals.

Previous studies shown that sagittal facial growth consists of vertical growth (base) and horizontal growth (front). If the vertical growth of facial sutures and alveolar process is greater than the growth of the condyle, the mandible turns back (clockwise direction), resulting in greater anterior facial height. On the other hand, if vertical growth of the condyle is larger than the sum of the components of vertical growth of facial sutures and alveolar process, the mandible turns to front (counterclockwise). The final growth vector is the result of the competition between horizontal and vertical growth. Longitudinal studies on growth may help answer some clinical questions: What changes might occur in the mandible during growth? Can the clinician detect during growth different directions of mandibular growth in Class I individuals? ${ }^{5,15,18}$

In the literature, studies concerning the development of Class II malocclusion are more frequent. 1,2,4,6,7,8,11,16,17 However, the literature shows that the morphological characteristics of malocclusions are still controversial and debated. Longitudinal studies of growth evaluating the development of Class $\mathrm{I}^{4,12,27}$ in horizontal and vertical patterns are scarce.

Based of the reduced number of researches concerning the assessment of differences in vertical and sagittal development of the mandible in untreated Class I individuals at different times of growth, new studies are anticipated with the aim of knowing the characteristics of these individuals, to evaluate facial shape tendency and to investigate longitudinal changes in mandibular growth. The knowledge of such data is critical to the success of orthodontic treatment, allowing the clinician to understand the behavior, of the mandible during growth and possible implications during the orthodontic treatment. 


\section{MATERIAL AND METHODS}

The sample comprised of 60 radiographs from the Burlington Growth Centre, University of Toronto, Canada, based on longitudinal records of 20 Class I individuals orthodontically untreated followed up at ages 9,12 and 21 years, being 10 individuals with vertical growth pattern and 10 horizontal .

In this longitudinal study, Group 1 with Class I malocclusion, vertical growth pattern $(n=10 ; 5$ male and 5 female) was compared with Group 2, comprised of Class I malocclusion with horizontal growth pattern ( $\mathrm{n}=10 ; 5$ male and 5 female). The sample was divided into 2 groups (vertical and horizontal), based on cephalometric measures in $\mathrm{T}_{1}$ : $\mathrm{SNA}$, SNB, ANB, SN.GoMe, NAP. ${ }^{25,26}$ Normal values of these measures for initial age of 9 years were described by Riedel, ${ }^{23} \mathrm{SNA}=80.79, \mathrm{SNB}=78.02, \mathrm{ANB}=2.77$, $\mathrm{SN} . \mathrm{GoMe}=32.27, \mathrm{NAP}=4.22$, values above or below the standard deviation of each measure characterize individuals with vertical or sagittal growth tendency, allowing the formation of two groups in this study.

The individuals were included according to the following criteria: 1) present cephalometric radiography from 9 to 21 years of age, 2) Class I malocclusion (ANB $\leq 4^{\circ}$ and $>0^{\circ}$ determined in $\mathrm{T}_{1}$ at 9 years ${ }^{23} 3$ ) Be healthy and without history of orthodontic treatment.

The sample belonging to the files of University of Toronto, Burlington Growth Centre Department was documented in the period 1952 to 1971. This material is the most extensive longitudinal study of craniofacial growth held up today. All the radiographs were made in the same X-ray machine with magnification of $9.84 \%$, with a constant focus / object distance and fixed in $152.4 \mathrm{~cm}$ and the chassis was positioned at a distance of $15 \mathrm{~cm}$ in the midsagittal plane of the individuals. ${ }^{22}$ In this study, 60 cephalometric tracings of the profile were conducted by the same operator, using $0.3 \mathrm{~mm}$ mechanical pencil with Ultraphan paper in negatoscope, in a dark room, framed with black cardboard, exposing the corresponding areas to anatomical drawing.

The points were then entered into a Numonics AccuGrid digitizing table and evaluated in computer by means of Dentofacial Planner Plus 2.01 software. Cephalometric analysis was composed by angular and linear measures (Figs 1 and 2), obtained through the program of computerized cephalometrics DFPlus. The mandibular behavior was examined at intervals of ages with reference to the lateral cephalograms.

To differentiate horizontal or vertical mandibular development component, the following linear and angular measures were used: SNB and Co-Gn, for analysis of horizontal position of the mandible (Fig 1). The vertical position was analyzed by means of the following measures (Fig 2): SN.GoMe angle, N-Me (anterior facial height) and S-Go (posterior facial height).

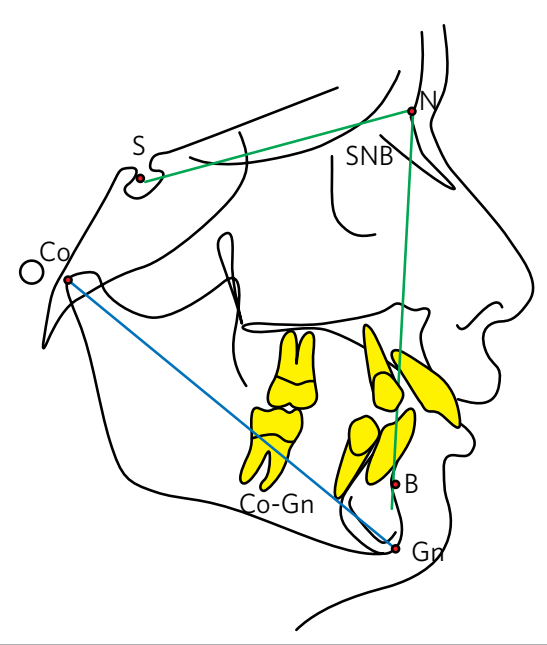

Figure 1 - Analysis of sagittal development was based on the following measures: SNB, Co-Gn. Reference points used: Sella turcica (S), Na$\operatorname{sion}(N)$, Point-B (B), Gnathion (NG), Condilio (Co).

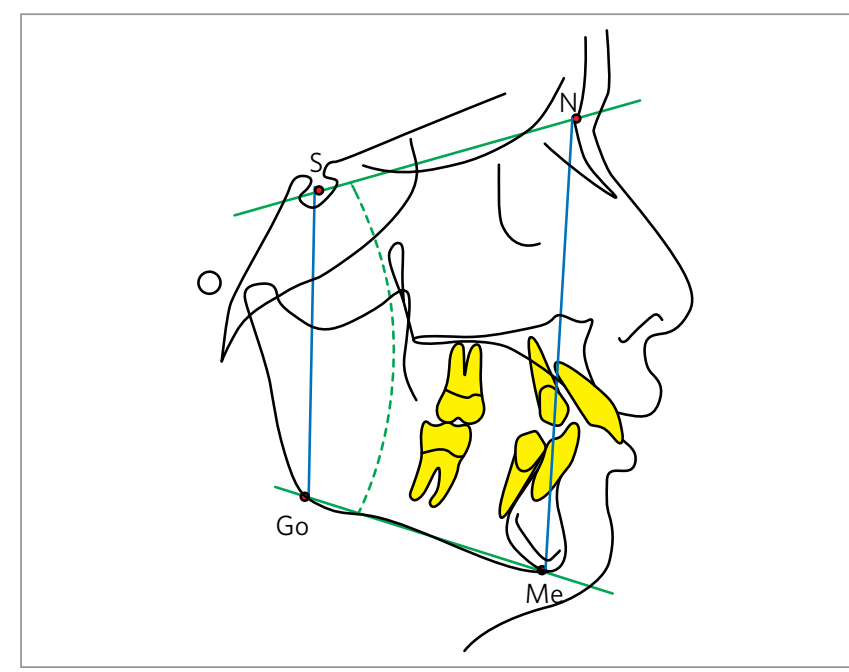

Figure 2 - Analysis of vertical development was based on the following measures: SN.GoMe; N-Me (AFH); S-Go (PFH). Reference points used: Sella turcica (S), Nasion (N), Gonion (Go), Menton (Me). 


\section{RESULTS}

The comparison of the mean of each of the measures in the two groups in each time was carried out using the Student's $t$ test for equality of two independent populations. Results show that the means of the measures SNB, SN.GoMe and AFH were different in the two groups, in all ages considered. The SN.GoMe value was greater in the group with horizontal growth at all ages. The SN.GoMe means were significantly higher in the group with horizontal growth and the AFH means were significantly higher in the group with vertical growth.

While there were significant differences in the means of $\mathrm{Co}-\mathrm{Gn}$ and $\mathrm{PFH}$ variables, it was observed that the means of the measure $\mathrm{Co}-\mathrm{Gn}$ and $\mathrm{PFH}$ were always higher in the group with horizontal growth pattern (Table 1).

To evaluate possible differences in the growth pattern of the two groups, the change that occurred in each individual, in two distinct ages, (between 9 and 12 years, between 12 and 21 years and between 9 and 21 years) was calculated, for each variable. The results presented in Table 2 show that, except for changes in SN.GoMe variable occurred between 9 and 21 years of age, there is no statistically significant difference in the mean of all other measures in any period considered. Despite the variation among the age groups have undergone changes in mean that can be clinically considered, when statistically measured, only SN.GoMe presented significant changes between 9 and 21 years of age.

\section{DISCUSSION}

In this longitudinal study, the sagittal and vertical mandible development on sample of Class I individuals with horizontal and vertical pattern were studied longitudinally in a period of clinical growth significance: Between 9, 12 and 21 years of age.

\section{Sagittal development}

In respect to the sagittal positioning of mandible among individuals with vertical and horizontal growth pattern a statistically different position between the two groups was observed. The angular (SNB) and linear (Co-Gn) measures indicated a mandibular retrognathism in individuals with Class I with vertical growth showing statistically significant differences between groups in SNB measures (Fig 3; Tables 1 and 2). The value of SNB and Co-Gn was higher in the group with horizontal growth in all ages. Thilander et $\mathrm{al}^{27}$ observed that the SNB angle increased continuously during the observation pe-

Table 1 - Means and standard deviations of the measures by age and group, and results of Student's $t$ test for the equality of means (independent populations).

\begin{tabular}{|c|c|c|c|c|c|c|c|c|}
\hline & \multicolumn{3}{|c|}{ Horizontal growth } & \multicolumn{3}{|c|}{ Vertical growth } & \multirow[b]{2}{*}{$\mathrm{gl}$} & \multirow[b]{2}{*}{$p$} \\
\hline & Age & mean & SD & mean & SD & $t$ & & \\
\hline \multirow{3}{*}{ SNB } & 9 & 80.1 & 3.13 & 73.4 & 1.90 & 5.80 & 18 & 0.000 \\
\hline & 12 & 80.7 & 3.03 & 73.7 & 3.24 & 4.95 & 18 & 0.000 \\
\hline & 21 & 83.0 & 2.99 & 75.0 & 2.80 & 6.16 & 18 & 0.000 \\
\hline \multirow{3}{*}{ SN.GoMe } & 9 & 31.4 & 3.40 & 40.4 & 3.35 & -5.94 & 18 & 0.000 \\
\hline & 12 & 30.2 & 2.74 & 41.3 & 3.31 & -8.17 & 18 & 0.000 \\
\hline & 21 & 28.6 & 4.02 & 40.3 & 3.17 & -7.21 & 18 & 0.000 \\
\hline \multirow{3}{*}{ Co-Gn } & 9 & 106.7 & 4.58 & 105.8 & 2.36 & 0.56 & 18 & 0.583 \\
\hline & 12 & 113.8 & 4.61 & 112.6 & 4.06 & 0.58 & 18 & 0.568 \\
\hline & 21 & 126.0 & 9.30 & 124.1 & 7.48 & 0.51 & 18 & 0.619 \\
\hline \multirow{3}{*}{ AFH } & 9 & 104.7 & 4.65 & 111.8 & 3.28 & -3.95 & 18 & 0.001 \\
\hline & 12 & 110.2 & 5.25 & 119.8 & 6.58 & -3.58 & 18 & 0.002 \\
\hline & 21 & 120.2 & 9.23 & 130.3 & 7.73 & -2.66 & 18 & 0.016 \\
\hline \multirow{3}{*}{ PFH } & 9 & 69.2 & 3.38 & 66.3 & 2.94 & 2.01 & 18 & 0.060 \\
\hline & 12 & 74.0 & 4.52 & 71.4 & 3.93 & 1.34 & 18 & 0.197 \\
\hline & 21 & 82.5 & 8.14 & 79.3 & 5.55 & 1.01 & 18 & 0.324 \\
\hline
\end{tabular}


Table 2 - Means and standard deviations of the changes in the measures, by group and period, and results of the Student's t test for the equality of averages (independent populations).

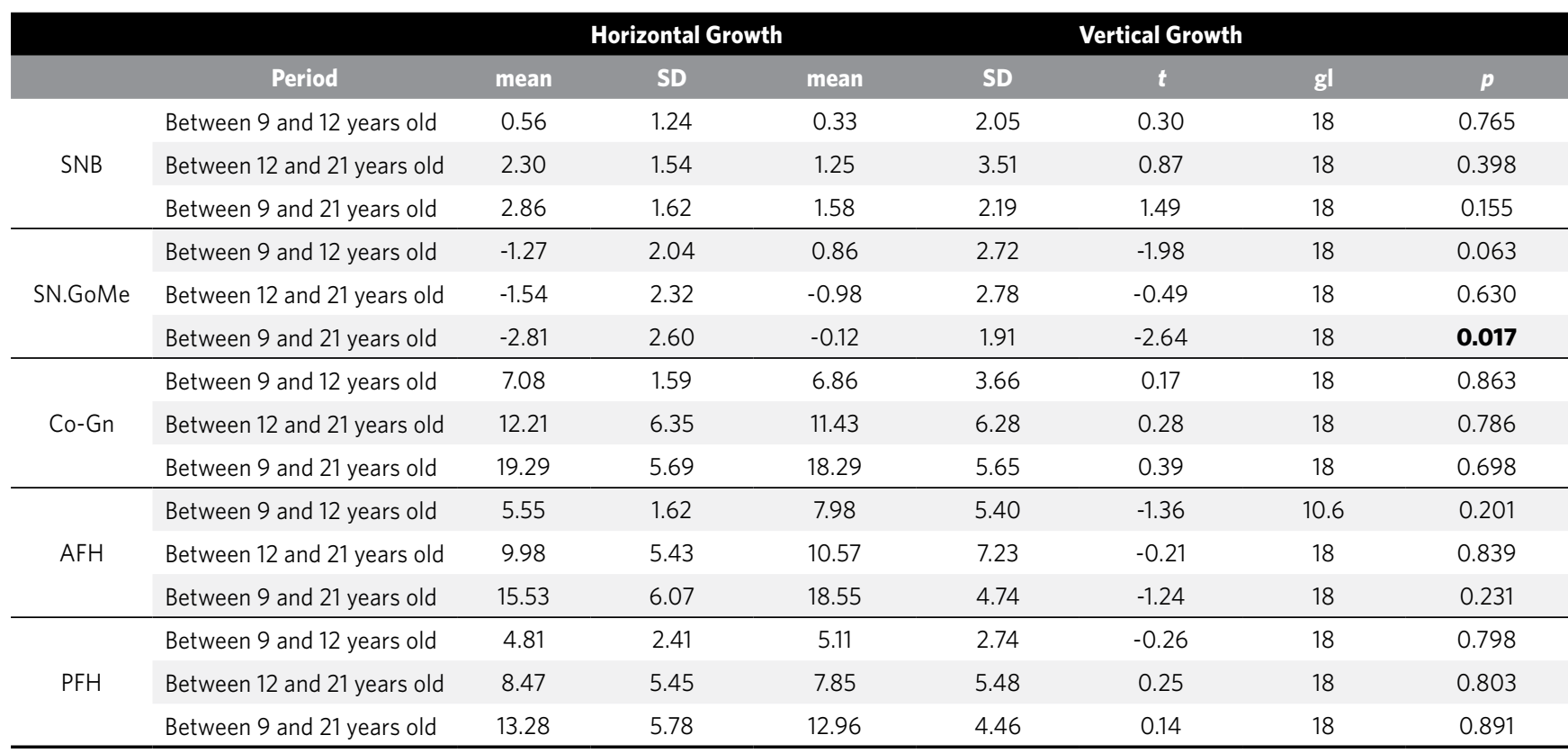

(1) student's t test for two population means with unequal variances.

riod, from 3 to 21 years in Class I individuals. Bishara et $\mathrm{al}^{4}$ longitudinally assessed Class II and normal individuals. In normal individuals the SNB angle increased during the period, not showing a significant Class II difference.

\section{Vertical development}

The vertical position was evaluated on the basis of angular and linear measures, SN.GoMe angle anterior facial height and posterior facial height (Fig 2; Tables 1 and 2).

The measure Sn.GoMe in individuals with horizontal growth pattern was significantly lower than in individuals with vertical growth. This angle shows a tendency to decrease with aging in subjects with hori- zontal growth. On the other hand, in individuals with vertical growth, this angle remains virtually the same between 9 and 21 years of age (Figure 3, Table 1 and 2). Thilander et $\mathrm{al}^{27}$ observed a tendency for mandibular counterclockwise rotation in Class I individuals. Class II individuals presented opposite behavior to Class I individuals with increased mandibular plane angle. ${ }^{21}$

The anterior facial height (AFH) presented lower values in individuals with horizontal growth pattern when compared to the vertical in all studied age groups (Fig 6, Tables 1 and 2). The SN.GoMe and AFH were always lower in the group with horizontal growth, which is in agreement with other authors following a pattern already demonstrated by Iseri et al. ${ }^{12}$

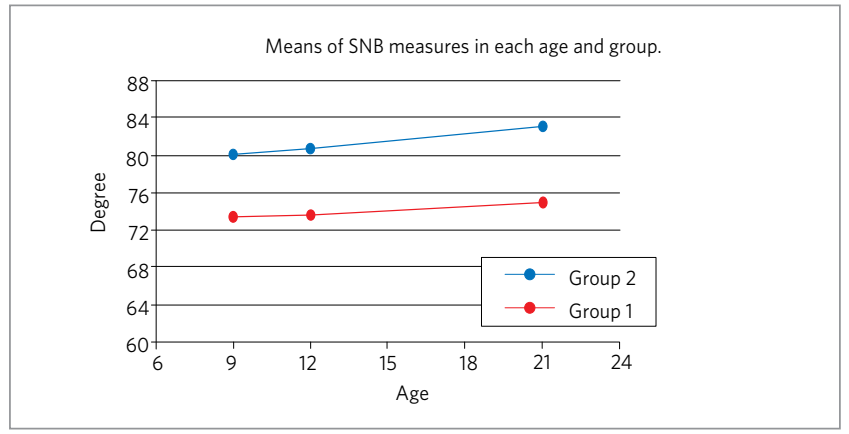

Figure 3 - Means of SNB measures in each age and group.

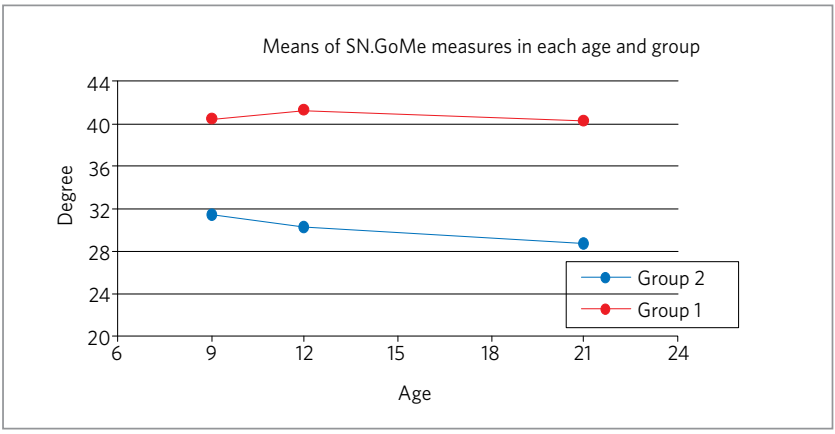

Figure 4 - Means of SN.GoMe measures in each age and group. 
The posterior facial height $(\mathrm{PFH})$ presented lower values in all age groups in individuals with vertical growth when compared to individuals with horizontal growth, although not statistically significant. The posterior facial height also influences other measures. Class I individuals with vertical growth presenting increased Sn.GoMe values, for example, show a tendency to a clockwise rotation of the mandible (Fig 7, Tables 1 and 2).

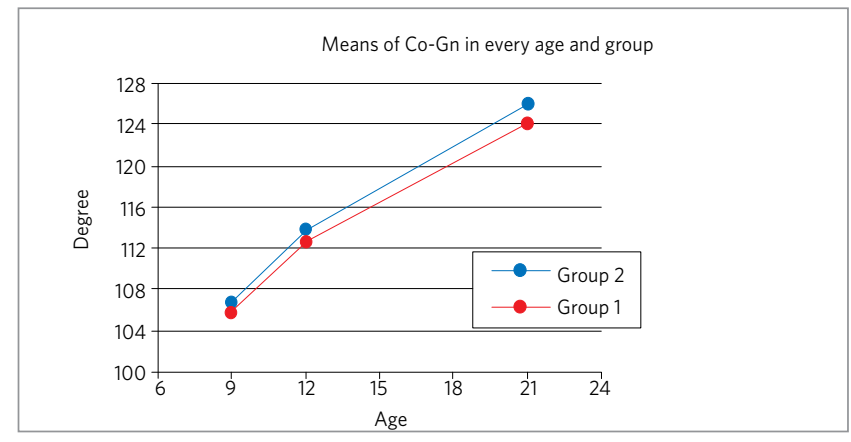

Figure 5 - Means of Co-Gn measures in every age and group.

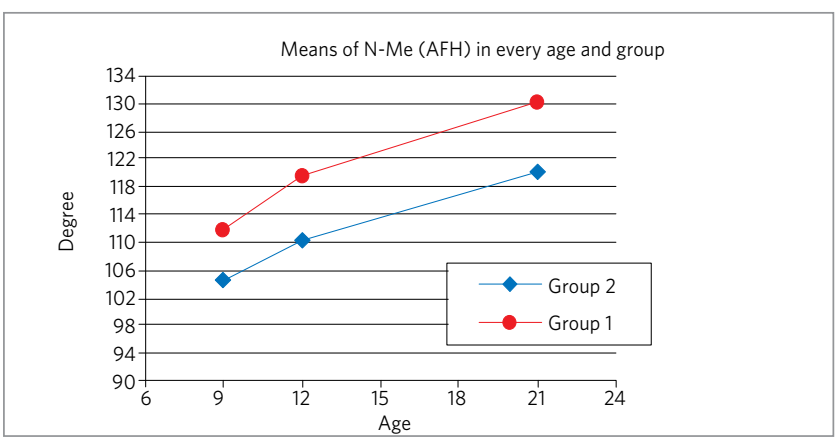

Figure 6 - Means of $\mathrm{N}-\mathrm{Me}(\mathrm{AFH})$ measures in every age and group.

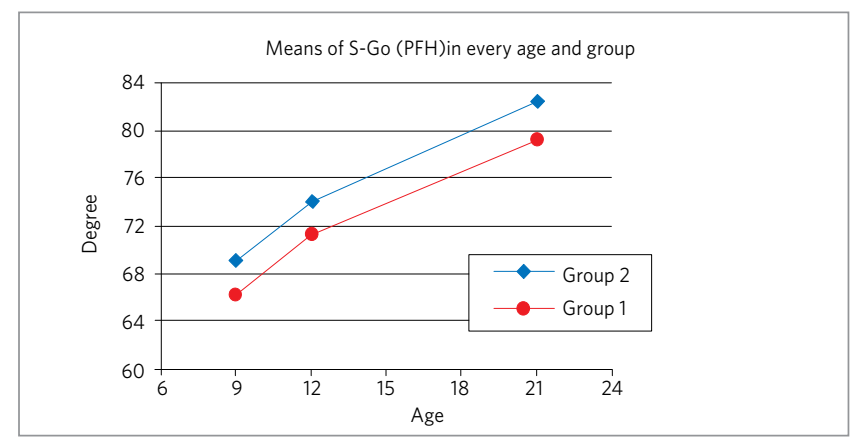

Figure 7 - Means of S-Go (PFH) measures in every age and group.

\section{Facial morphology}

The anterior facial height showed significant increase in Group 1 (vertical) when compared with Group 2. Changes were noted in this measure among the ages in Group 2, as the increase of anterior facial height is significantly lower in this group.

\section{CONCLUSIONS}

\section{Sagittal development}

In the sample of individuals with vertical growth pattern, a greater retrognathism was noted when compared with the other group. The retrognathic position of the mandible, in the vertical group, was present at 9 years of age, and the growth increment was similar in both groups studied.

In the group with horizontal growth pattern the position of the mandible varied, presenting more orthognathic position.

\section{Vertical development}

In the group with horizontal growth pattern, there was a deficit in terms of anterior facial height. This deficit was not found in the vertical facial development group. In addition, increases in development of anterior facial height at the time between 9 and 21 years of age were significantly lower in Class I horizontal pattern.

\section{Facial shape}

Despite of inter-group differences being statistically significant for some measures, Class I horizontal group showed a more brachycephalic tendency in facial shape. It is suggested that the deviation of the facial morphology could be caused by the deficit in vertical development of anterior facial height. 


\section{REFERENCES}

1. Altemus LA. Horizontal and vertical dentofacial relationships in normal and Class II division 1 in girls 11-15 years. Angle Orthod. 1955; 25:120-37.

2. Baccetti T, Franchi L, McNamara JA Jr, Tollaro I. Early dentofacial features of Class II malocclusion: a longitudinal study from the deciduous through the mixed dentition. Am J Orthod Dentofacial Orthop. 1997;111(5):502-9.

3. Baumrind S, Miller D, Molthen R. The reliability of head film measurements. 3 . Tracing superimposition. Am J Orthod. 1976;70(6):617-44.

4. Bishara SE, Jakobsen JR, Vorhies B, Bayati P. Changes in dentofacial structures in untreated Class II division 1 and normal subjects: a longitudinal study. Angle Orthod. 1997;67(1):55-66

5. Broadbent B, Holly S, Broadbent BH, Golden WY. Bolton standards of dentofacial developmental growth. St. Louis: C.V. Mosby; 1975.

6. Buschang PH, Tanguay R, Turkewicz J, Demirjian A, La Palme L. A polynomial approach to craniofacial growth: description and comparison of adolescent males with normal occlusion and those with untreated Class II malocclusion. Am J Orthod Dentofacial Orthop. 1986;90(5):437-42.

7. Buschang PH, Martins J. Childhood and adolescent changes of skeletal relationships. Angle Orthod. 1998;68(3):199-206.

8. Carter NE. Dentofacial changes in untreated Class II Division 1 subjects. $\mathrm{Br}$ Orthod. 1987;14:225-34.

9. Chung C, Wong WW. Craniofacial growth in untreated skeletal Class II subjects: a longitudinal study. Am J Orthod Dentofacial Orthop. 2002;122(6):619-26.

10. Gallagher RW, Miranda F, Buschang PH. Maxillary protraction: treatment and posttreatment effects. Am J Orthod Dentofacial Orthop. 1998;113(6):612-9.

11. Godiawala RN, Joshi MR. A cephalometric comparison between Class II, Division 2 malocclusion and normal occlusion. Angle Orthod. 1974;44(3):262-7.

12. Iseri $\mathrm{H}$, Solow $\mathrm{B}$. Growth displacement of the maxilla in girls studied by the implant method. Eur J Ortod Soc. 1990;12:389-98.

13. Kalra V, Burstone CJ, Nanda R. Effects of a fixed magnetic appliance on the dentofacial complex. Am J Orthod Dentofacial Orthop. 1989;95(6):467-78.

14. Kolodziej RP, Southard TE, Southard KA, Casko JS, Jakobsen JR. Evaluation of antegonial notch depth for growth prediction. Am J Orthod Dentofacial Orthop. 2002;121(4):357-63.

15. Love RJ, Murray JM, Mamandras AH. Facial growth in males 16 to 20 years of age. Am J Orthod Dentofacial Orthop. 1990;97(3):200-6.
16. Lux CJ, Conradt C, Burden D, Komposch G. Dental arch widths and mandibularmaxillary base widths in Class II malocclusions between early mixed and permanent dentitions. Angle Orthod. 2003;73(6):674-85.

17. Lux CJ, Raeth O, Burden D, Conradt C, Komposch G. Sagittal and vertical growth of the Jaws in Class II, Division 1 and Class II, Division 2 malocclusions during prepubertal and pubertal development. J Orofac Orthop. 2004;65(4):290-311.

18. McNamara JA. Components of Class II malocclusion in children 8-10 years of age. Angle Orthod. 1981;51(3):177-202.

19. Mobarak KA, Krogstad O, Espeland L, Lyberg T. Factors influencing the predictability of soft tissue profile changes following mandibular setback surgery. Angle Orthod. 2001;71(3):216-27.

20. Mogavero FJ, Buschang PH, Wolford LM. Orthognathic surgery effects on maxillary growth in patients with vertical maxillary excess. Am J Orthod Dentofacial Orthop. 1997;111:288-96.

21. Ngan PW, Byczek E, Scheick J. Longitudinal evaluation of growth changes in Class II Division 1 subjects. Semin Orthod. 1997;3(4):222-31.

22. Requirements and limitations of roentgenographic cephalometry. Burlington Growth Center. Toronto: University of Toronto; 1962.

23. Riedel RA. The relation of maxillary structures to cranium in malocclusion and normal occlusion. Angle Orthod. 1952;22(3):142-5

24. Riolo ML, Moyers RE, McNamara JA Jr, et al. An atlas of craniofacial growth Monograph No. 2; Craniofacial Growth Series. Center for Human Growth and Development. Ann Arbor, MI: Center for Human Growth and Development, The University of Michigan; 1974.

25. Schudy FF. Vertical growth versus anteroposterior growth as related to function and treatment. Angle Orthod. 1964;34(2):75-93.

26. Schudy FF. The rotation of the mandible resulting from growth: its implications in orthodontic treatment. Angle Orthod. 1965;35:36-50.

27. Thilander B, Persson M, Adolfsson U. Roentgen-cephalometric standards for a Swedish population. A longitudinal study between the ages of 5 and 31 years. Eur J Orthod. 2005;27(4):370-89.

28. Tulloch JF, Medland W, Tuncay OC. Methods used to evaluate growth modification in Class II malocclusion. Am J Orthod Dentofacial Orthop. 1990;98(4):340-7. 